\title{
RELAÇÕES ENTRE DIREITO E MORAL: VINCULAÇÃO, SEPARAÇÃO E AS CONTRIBUIÇÕES DE HABERMAS E NINO
}

\section{Bruno Cunha Weyne}

Mestre em Direito (UFC). Professor-substituto da Faculdade de Direito (UFC).

brunoweyne@yahoo.com.br

Sumário: Introdução. 1. A vinculação entre Direito e moral e o jusnaturalismo. 2. A separação entre Direito e moral e o positivismo jurídico. 3. A complementaridade recíproca entre Direito e Moral segundo Habermas. 4. O discurso de justificação do Direito e a tese da vinculação segundo Nino. Conclusão. Referências.

Resumo: O artigo pretende apresentar as principais teorias acerca da relação entre Direito e moral, assinalando as contribuições da filosofia jurídica contemporânea de Jürgen Habermas e de Carlos Santiago Nino. Para realizar essa tarefa, o texto divide-se em duas partes: a primeira examina as teses da vinculação e da separação entre Direito e moral de acordo com o jusnaturalismo e com o positivismo jurídico, respectivamente; a segunda parte analisa as propostas de Habermas e Nino sobre a relação entre Direito e moral e investiga como elas podem superar o debate tradicional.

Palavras-chave: Direito e moral. Jürgen Habermas. Carlos Santiago Nino.

\section{INTRODUÇÃo}

A discussão em torno da relação entre Direito e moral é uma das mais antigas e também mais relevantes da Filosofia do Direito, já que "constitui o principal problema na polêmica acerca do conceito de Direito" (ALEXY, 2009 , p. 3), assim como envolve a própria questão da legitimidade do Direito. Para Robert Alexy (2009, p. 3-4), duas posições fundamentais sobre essa relação podem ser identificadas: a positivista e a não positivista. Ele afirma que todas as teorias positivistas defendem a tese da separação, segundo a qual o conceito de Direito não deve incluir elementos morais, ao passo que todas as teorias não positivistas defendem a tese da vinculação, segundo a qual o conceito de Direito deve conter tais elementos. 
Como será visto adiante, pode-se observar que, embora todos os jusnaturalistas defendam a tese da vinculação, Alexy tem razão em não reduzir a defesa dessa tese apenas a essa linha de pensamento, uma vez que o debate filosófico-jurídico contemporâneo apresenta novas perspectivas - dentre as quais duas serão aqui abordadas - para se repensar a relação entre Direito e moral a partir da ideia de uma vinculação entre tais saberes.

Este trabalho tem como objetivo, em primeiro lugar, expor criticamente as teorias explicativas da relação entre Direito e moral a partir do jusnaturalismo (tese da vinculação) e do positivismo jurídico (tese da separação). Em segundo lugar, busca-se apresentar as propostas de Jürgen Habermas, que sustenta uma relação de complementaridade recíproca entre Direito e moral, e de Carlos Santiago Nino, que entende ser inevitável o recurso à moral na tarefa de justificação do Direito. Dessa maneira, procura-se averiguar como a contribuição desses autores contemporâneos implica uma superação do debate tradicional entre jusnaturalismo e positivismo jurídico sobre a relação entre Direito e moral.

Diante do caráter hermenêutico desta investigação, utilizou-se como metodologia a pesquisa bibliográfica, baseada no levantamento, na leitura e elaboração de fichamentos críticos dos livros e artigos científicos referenciados ao final do texto. Ainda sobre o aspecto metodológico, convém destacar que os debates no Grupo de Pesquisa Filosofia dos Direitos Humanos (CNPq/UFC) foram de suma importância para o desenvolvimento das ideias ora apresentadas, uma vez que o tema central do presente trabalho relaciona-se diretamente com a reflexão filosófica sobre os direitos humanos, como, por exemplo, no que concerne ao caráter normativo e ao papel desses direitos dentro da ordem jurídica estatal.

\section{A Vinculação entre Direito e Moral e o Jusnaturalismo}

$\mathrm{O}$ antigo debate entre o jusnaturalismo e o positivismo jurídico gira em torno da relação entre Direito e moral ${ }^{1}$. De uma maneira bem geral, pode-se afirmar que, enquanto o jusnaturalismo sustenta que há uma vinculação intrínseca entre Direito e moral, o positivismo jurídico nega tal vinculação². No entanto, dentro da ideia de que existe uma vinculação entre Direito e moral podem enquadrar-se várias doutrinas jusnaturalistas com teses distintas sobre essa vinculação. Mas, afinal de contas, qual é a tese sobre a relação entre Direito e moral que o jusnaturalismo defende e que o juspositivismo rechaça? Dito de outro modo:

\footnotetext{
${ }^{1}$ A esse respeito, cf. NINO (2007b, p. 16-43).

${ }^{2}$ Deve-se reiterar aqui que, embora a tese da separação seja defendida por todo positivista, a tese da vinculação não é defendida apenas pelos jusnaturalistas, haja vista que a filosofia jurídica contemporânea oferece propostas de releitura da relação entre Direito e moral a partir da ideia de uma conexão entre esses saberes. Cf. tópicos 4 e 5 deste trabalho.
} 
é possível falar de uma tese geral que toda doutrina jusnaturalista tem de aderir para assim ser chamada? Nino (2007b, p. 28) responde que sim, argumentando que duas são as teses que caracterizam o jusnaturalismo:

a) Uma tese de filosofia ética que sustenta que há princípios morais e de justiça universalmente válidos e acessíveis à razão humana.

b) Uma tese acerca da definição do conceito de Direito, segundo a qual um sistema normativo ou uma norma jurídica não podem ser qualificados de jurídicos se contradizem aqueles princípios morais ou de justiça.

Acrescenta o aludido autor que, embora os jusnaturalistas coincidam na defesa dessas duas teses, eles discrepam no que tange à origem ou ao fundamento dos princípios morais e de justiça que vão conformar o chamado "Direito natural" e acerca de quais são tais princípios. Norberto Bobbio (1997, p. 61) parece concordar com a tese $a$, na medida em que afirma que "Historicamente, sempre se chamou de 'jusnaturalista' quem acreditou na existência de leis da conduta universalmente válidas e, também, na possibilidade de descobri-las na natureza por meio da razão". Ambas as teses serão avaliadas com base em uma breve análise do pensamento de três filósofos que, apesar de pertencerem a distintos períodos históricos, são tidos como emblemáticos jusnaturalistas, a saber: Aristóteles, Tomás de Aquino e John Locke.

No Capítulo 7, do Livro V, da sua Ética a Nicômaco, Aristóteles (2002, p. 151) trata da distinção entre Direito natural e Direito positivo, afirmando o seguinte:

A justiça política é em parte natural, em parte convencional. Uma regra de justiça natural é aquela que apresenta idêntica validade em todos os lugares e não depende de nossa aceitação ou inaceitação. Uma regra convencional é aquela que, em primeira instância, pode ser estabelecida de uma forma ou outra indiferentemente, ainda que uma vez estabelecida, deixa de ser indiferente.

A partir desse trecho, percebe-se que o Direito natural é definido por meio de duas características: a primeira é a sua validade universal, independentemente do lugar, visto que, segundo Aristóteles (2002, p. 152), o Direito natural é determinado pela natureza, quer dizer, é algo tão natural como o fogo que queima tanto na Grécia quanto na Pérsia; a segunda característica refere-se ao fato de as regras de justiça natural não dependerem da aceitação das pessoas, pois determinam o que é justo ou injusto por si mesmas.

No que tange ao Direito positivo, Aristóteles caracteriza-o com base tão somente na oposição da segunda característica, não se reportando à oposição da primeira. Contudo, em comentário ao trecho citado, Bobbio (1997, p. 33-34) esclarece que o oposto da primeira característica pode ser subentendido: "contrariamente ao direito natural, que tem a mesma eficácia em toda parte, podemos 
atribuir ao direito positivo, sem que Aristóteles precise dizê-lo, a característica de mudar de lugar para lugar, de ter validade particular e não universal”. A característica do Direito positivo indicada por Aristóteles é a seguinte: enquanto o Direito natural estabelece uma esfera de comportamentos em que são obrigatórias as ações boas ou más por si mesmas, independentemente da vontade humana, o Direito positivo trata justamente da esfera de ações indiferentes aos comandos do Direito natural: "Em outras palavras, as ações regidas pelo direito positivo são aquelas que seriam livres, não fosse o comando ou a proibição do direito positivo" (BOBBIO, 1997, p. 34). Importa verificar o que aconteceria se uma lei positiva regulasse uma conduta de forma contrária ao que uma lei natural prescreve. Embora não haja ainda em Aristóteles a moderna noção dualista moralidade/legalidade ${ }^{3}$, esse autor deixa claro, em sua obra Retórica, a preferência por um Direito natural quando coloca em evidência a excelência das leis não escritas, referindo-se inclusive ao exemplo de Antígona, quando ela desobedece à lei positiva de Creonte em favor de uma lei superior a esta: "[...] o razoável permanece sempre e nunca muda, como tampouco a lei geral (pois é conforme à natureza), enquanto que as escritas o fazem com frequência; daí o que se diz na Antígona de Sófocles, quando ela se defende por haver sepultado seu irmão contra a lei de Creonte, mas não contra a não escrita" (ARISTÓTELES, 1998, p. 130).

Na sua Suma Teológica, Tomás de Aquino formula um jusnaturalismo de cunho teológico. Aqui, o direito ou lei natural é uma espécie do gênero lei. Para ele, toda lei consiste em "uma ordenação da razão para o bem comum, promulgada por aquele que tem o cuidado da comunidade" (AQUINO, 2005, p. 527-528). Distingue quatro espécies de lei: a lei eterna, a lei natural, a lei divina e a lei humana.

A lei eterna é a sabedoria divina enquanto princípio diretivo de todo ato e de todo movimento no mundo. Conquanto ninguém possa apreender direitamente a lei eterna tal como ela é em si mesma, toda criatura racional a conhece, de maneira mais ou menos perfeita, através dos princípios comuns da lei natural, a qual nada mais é do que a participação da lei eterna na criatura racional. O primeiro e mais básico preceito da lei natural se funda na noção de bem: "o bem deve ser feito e procurado; e o mal, evitado" (AQUINO, 2005, p. 562). Sobre esse preceito se fundam todos os demais preceitos da lei natural. Como os juízos humanos podem vacilar a respeito de determinados assuntos, Deus revelou alguns preceitos, para que o homem possa saber, sem nenhuma dúvida, aquilo que deve fazer ou evitar, tal como os Dez Mandamentos. Esses preceitos constituem a lei divina. Finalmente, a lei humana abrange todos os preceitos particulares descobertos pela razão humana, a fim de enfrentar as diferentes situações criadas

\footnotetext{
"A ação boa e justa não é, para Aristóteles, a ação moral do indivíduo isolado da modernidade, mas a ação humana, e enquanto tal situada num feixe de relações. Aristóteles nunca conheceu a forma moderna da separação entre o indivíduo e a esfera política, como ela se explicitou, por exemplo, na separação kantiana entre moralidade e legalidade [....]" (OLIVEIRA, 1993, p. 57).
} 
pelo relacionamento entre os indivíduos. A lei humana, como enfatiza Tomás de Aquino (2005, p. 576), deve ajustar-se aos preceitos da lei natural: “[...] toda lei humanamente imposta tem tanto de razão de lei quanto deriva da lei da natureza. Se, contudo, em algo discorda da lei natural, já não será lei, mas corrupção da lei”.

Na filosofia de John Locke (1994, p. 88), o Direito natural é uma lei não escrita, derivada da razão e absolutamente inteligível a todos os homens que se dediquem ao seu estudo, sendo possivelmente mais clara que as leis positivas da comunidade civil, "pois a razão é mais fácil de ser compreendida que os sonhos e as maquinações intrincadas dos homens, buscando reduzir em palavras interesses contrários e ocultos". Esse Direito natural é válido tanto no estado de natureza quanto na sociedade civil e, através dele, "toda a humanidade aprende que, sendo todos iguais e independentes, ninguém deve lesar o outro em sua vida, sua saúde, sua liberdade ou seus bens" (LOCKE, 1994, p. 84).

Locke deixa claro, em várias passagens do seu Segundo Tratado sobre o Governo Civil, que o Direito natural, além de acessível à razão humana, possui origem divina. Nessa perspectiva, ele afirma que "todos os homens são obra de um único Criador todo-poderoso e infinitamente sábio, todos servindo a um único senhor soberano, enviados ao mundo por sua ordem e a seu serviço; são portanto sua propriedade [...]" (LOCKE, 1994, p. 84). Do mesmo modo, sustenta que todas as regras que regem as ações humanas devem "estar de acordo com a lei da natureza, isto é, com a vontade de Deus, da qual ela é a declaração; como a lei fundamental da natureza é a preservação da humanidade, nenhuma sanção humana pode ser boa ou válida contra ela" (LOCKE, 1994, p. 164, grifo nosso). Como se vê, o Direito positivo deve adotar os preceitos do Direito natural como parâmetro de justiça. Nas palavras de Locke (1994, p. 88): "[as leis civis dos países] só são justas na medida em que se baseiam na lei da natureza, pela qual devem ser regulamentadas e interpretadas".

Após essa análise, pode-se constatar que a tese $a$ proposta por Nino, segundo a qual todo jusnaturalista defende que há certos princípios morais ou de justiça universalmente válidos e acessíveis à razão humana, está realmente presente no pensamento dos três autores citados. No que se refere à tese $b$, segundo a qual um sistema normativo ou uma norma jurídica não podem ser qualificados como jurídicos se contradizem aqueles princípios morais ou de justiça, percebe-se que ela exige um esclarecimento mais preciso. Pois bem, a ideia- chave que está por trás da tese $b$ é a de que o Direito positivo deve estar de acordo com o Direito natural, havendo uma verdadeira relação de subordinação de um em face do outro, sob pena de o primeiro ser considerado injusto, ilegítimo, ou ainda, inválido. Com isso, Nino pretende demonstrar que, para o jusnaturalismo em geral, um Direito em desacordo com os princípios morais ou de justiça é um Direito que não tem valor autêntico, daí não poder ser qualificado com o adjetivo "jurídico". Nesse 
caso, surge necessariamente uma exigência deontológica de reforma da ordem positiva. Feitas essas ponderações, observa-se que a tese $b$ também está presente no pensamento dos três autores estudados.

\section{ASeparação entre Direito e Moral e o Positivismo Jurídico}

Como visto anteriormente, o positivismo jurídico sustenta a tese de que inexiste qualquer vinculação entre Direito e moral, havendo uma verdadeira separação entre eles. Todavia, considerando que existem várias vertentes juspositivistas acerca de como se opera essa separação, também aqui se pode perguntar se existe alguma tese geral que caracterize uma doutrina jurídica como positivista. Segundo Nino (2007b, p. 37), aquilo que caracteriza o positivismo jurídico é "a tese de que o conceito de Direito não deve caracterizar-se segundo propriedades valorativas, mas sim levando em consideração apenas propriedades descritivas". Acrescenta que, segundo essa tese, "as proposições acerca do que o Direito dispõe não implicam juízos de valor e são verificáveis em relação a certos fatos observáveis empiricamente" (NINO, 2007b, p. 37). No mesmo sentido, Samuel Schuman (1963, p. 121) afirma que o positivismo jurídico "é tanto a aceitação da tese de que Direito e moral estão separados quanto a aceitação de determinada teoria sobre a natureza da moral referida ao não cognitivismo". Para verificar como essas teses manifestam-se nas doutrinas juspositivistas, analisarse-á criticamente o pensamento de Hans Kelsen, que é tido por muitos como um representante emblemático do positivismo jurídico.

No capítulo II, da sua Teoria Pura do Direito, Kelsen (2003, p. 68) argumenta inicialmente que a distinção entre Direito e moral não pode referir-se à conduta que prescrevem essas ordens sociais: "O suicídio não pode ser apenas proibido pela moral, mas tem de o ser também pelo Direito; a coragem e a castidade não podem ser apenas deveres morais - são também deveres jurídicos". O autor acrescenta que também é errada a concepção frequente de que o Direito prescreve uma conduta externa e a moral uma conduta interna, uma vez que ambos os tipos de condutas - externa e interna - seriam prescritas pelas duas ordens sociais referidas ${ }^{4}$. Kelsen (2003, p. 68), aludindo à ética kantiana, interpreta-a no

\footnotetext{
4 "A virtude moral da coragem não consiste apenas no estado de alma de ausência de medo, mas também em uma conduta exterior condicionada por aquele estado. E, quando uma ordem jurídica proíbe o homicídio, proíbe não apenas a produção da morte de um homem através da conduta exterior de um outro homem, mas também uma conduta interna, ou seja, a intenção de produzir um tal resultado" (KELSEN, 2003, p. 68). Aqui, Kelsen parece afastar-se do ponto central da discussão sobre a conduta externa e conduta interna, que será mais bem trabalhada no tópico 4 deste texto. Tal discussão refere-se ao fato de o Direito retirar o fardo motivacional que uma norma moral (racional) requer, ou seja, a conduta exigida pelo Direito prescinde da intenção do agente, satisfazendo-se perfeitamente com a obediência à norma jurídica por medo da sanção; já a conduta exigida por uma moral da razão - em termos kantianos - só encontra seu valor na medida em que é praticada por dever moral, independentemente de qualquer fator empírico - inclinações, interesses, desejos etc. Como Kelsen não aceita a ideia de uma moral da razão, é de certa forma compreensível o sentido da sua argumentação.
} 
sentido de que, diferentemente do Direito, a conduta interna que a moral exige "deverá consistir em uma conduta que, para ser moral, terá de ser realizada contra a inclinação" (grifo nosso).

O comentário de Kelsen sobre a proposta de Kant, contudo, não é completamente fiel ao pensamento original deste autor. Kant (1995, p. 38) entende que a ação não é moralmente boa por aquilo que se promove ou realiza, quer dizer, o valor moral da ação não reside no efeito que dela se espera: "nada senão a representação da lei em si mesma, que em verdade só no ser racional se realiza, enquanto é ela, e não no efeito esperado, que determina a vontade, pode constituir o bem excelente a que chamamos moral". Isso significa dizer que o valor moral da ação consiste em fazer o bem, não por inclinação, mas por dever. Observe-se, portanto, que a ação, para ser moral, não deve ser praticada "contra a inclinação", mas sim praticada pura e voluntariamente por dever - ou seja, por respeito à lei. A diferença, embora possa parecer sutil, confere mais destaque à oposição à inclinação do que à própria ideia de respeito à lei. Esse distanciamento do pensamento kantiano, na verdade, tem relação com a posição cética de Kelsen a respeito da possibilidade de uma moral da razão universalmente válida.

Kelsen (2003, p. 70) argumenta, em seguida, que o Direito e a moral tampouco se distinguem essencialmente com referência à produção ou à aplicação das suas normas: "Tal como as normas do Direito, também as normas da moral são criadas pelo costume ou por meio de uma elaboração consciente [...]. Neste sentido a moral é, como o Direito, positiva, e só uma moral positiva tem interesse para uma ética científica, tal como apenas o Direito positivo interessa a uma teoria científica do Direito". Antes de entrar no mérito da relatividade da moral, Kelsen (2003, p. 71) afirma que a única distinção entre Direito e moral não pode ser encontrada naquilo que as duas ordens sociais prescrevem ou proíbem, mas sim como elas prescrevem ou proíbem as condutas humanas:

O Direito só pode ser distinguido essencialmente da moral quando [...] se concebe como uma ordem de coação, isto é, como uma ordem normativa que procura obter uma determinada conduta humana ligando à conduta oposta um ato de coerção socialmente organizado, enquanto a moral é uma ordem social que não estatui quaisquer sanções desse tipo, visto que as suas sanções apenas consistem na aprovação da conduta conforme às normas e na desaprovação da conduta contrária às normas, nela não entrando sequer em linha de conta, portanto, o emprego da força física.

Para Kelsen, as relações entre Direito e moral podem ser abordadas tanto quanto à forma como quanto ao conteúdo. No que tange à forma, as considerações feitas até então já revelam a posição do autor sobre o assunto. No que diz respeito ao conteúdo, há aqueles que afirmam que "o Direito por sua própria 
essência tem um conteúdo moral ou constitui um valor moral, com isso afirma-se que o Direito vale no domínio da moral, que o Direito é uma parte constitutiva da ordem moral, que o Direito é moral e, portanto, é por essência justo" (KELSEN, 2003, p. 72). A justificação do Direito por esta tese tem de pressupor que apenas uma única moral é a válida, ou seja, uma moral absoluta, que fornece valores morais absolutos, os quais serão os únicos aptos a legitimar o Direito.

Segundo Kelsen (2003, p. 72), no entanto, essa linha de raciocínio é insustentável do ponto de vista de um conhecimento científico, já que "um valor absoluto apenas pode ser admitido com base em uma crença religiosa na autoridade absoluta e transcendente da divindade". Desse modo, argumentando que é impossível determinar qualquer elemento comum às diferentes ordens morais positivas, Kelsen (2003, p. 73) afirma que só é correto falar de valores relativos e de uma moral relativa: "Com efeito, quando se não pressupõe a priori como dado, isto é, quando se não pressupõe qualquer valor moral absoluto, não se tem qualquer possibilidade de determinar o que é que tem de ser havido, em todas as circunstâncias, por bom e mau, justo e injusto". Para ele, a única coisa comum a todos os sistemas morais possíveis é a sua forma, o dever-ser, o caráter de norma. Deduz, nesse sentido, que "a questão das relações entre o Direito e a moral não é uma questão sobre o conteúdo do Direito, mas uma questão sobre a sua forma" (KELSEN, 2003, p. 74).

Ao se filiar a uma teoria relativa dos valores, Kelsen sustenta que a validade de uma ordem jurídica positiva independe da sua concordância ou discordância com qualquer sistema de moral, visto que não há uma moral ou uma justiça absolutas. Assim sendo, a legitimação do Direito pela moral (positiva) é irrelevante, porquanto, para Kelsen (2003, p. 77), não é tarefa da ciência jurídica aprovar ou desaprovar o seu objeto, mas apenas conhecê-lo e descrevê-lo: "[...] a tarefa da ciência jurídica não é de forma alguma a valoração ou apreciação do seu objeto, mas uma descrição do mesmo alheia a valores. O jurista científico não se identifica com qualquer valor, nem mesmo com o valor jurídico por ele descrito". Diante dessas considerações, Kelsen conclui que não existe uma relação de vinculação entre Direito e moral, como pretendem os jusnaturalistas. Do ponto de vista do conhecimento dirigido ao Direito positivo, exige-se uma separação entre Direito e moral, sendo possível, como visto anteriormente, que uma norma jurídica seja considerada válida ainda que contrarie uma ordem moral.

Alguns questionamentos importantes podem ser levantados contra o positivismo jurídico: ao se limitar à tarefa cognitivo-descritiva do Direito, deixando de lado a tarefa de legitimação do ordenamento jurídico, o jurista científico de Kelsen não permitirá que toda sorte de critérios ingressem no Direito positivo? Em outras palavras: é possível e desejável que a validade de uma norma jurídica independa de critérios morais? No mesmo sentido, pode-se perguntar o seguinte: 
é possível e desejável que o jurista não se identifique com qualquer valor ao realizar o seu labor científico de conhecer e descrever o Direito? Essas intrigantes questões serão analisadas nas partes subsequentes deste texto, nas quais serão abordadas duas propostas da filosofia jurídica contemporânea sobre as relações entre Direito e moral. De um lado, Habermas busca superar, de maneira crítica, o debate tradicional entre jusnaturalismo e juspositivismo, sustentando que o Direito e a moral são saberes autônomos, que se complementam reciprocamente em sua tarefa comum de ordenar legitimamente as relações interpessoais. De outro lado, Nino pretende demonstrar, logicamente, que o Direito não tem uma "autonomia justificatória", subsistindo uma inevitável subordinação do Direito em face da moral, especificamente no que concerne à legitimação daquele.

\section{A Complementaridade Recíproca entre Direito e Moral Segundo Habermas}

Para além das tradicionais teorias explicativas da relação entre Direito e moral a partir das noções de subordinação e separação, Habermas prefere esclarecê-la a partir de uma relação sociológica complementar ${ }^{5}$. Para ele, o Direito moderno, ao manter a distinção entre Direito natural e Direito positivo, apega-se a uma reduplicação do conceito de Direito que não é plausível nem do ponto de vista sociológico nem do ponto de vista normativo: "Eu penso que no nível de fundamentação pós-metafísico, tanto as regras morais como as jurídicas diferenciam-se da eticidade tradicional, colocando-se como dois tipos diferentes de normas de ação, que surgem lado a lado, complementando-se" (HABERMAS, 2003, p. 139).

Segundo Habermas, Kant, na sua Metafísica dos Costumes, não procede de acordo com essa noção de complementaridade, uma vez que ele extrai o "princípio geral do Direito" da aplicação do conceito fundamental da lei da liberdade moral a "relações externas". Tanto na concepção kantiana quanto na reduplicação do conceito de Direito em Direito natural e Direito positivo subjaz uma herança platônica (relação de subordinação normativa do Direito à moral), ou seja, a intuição segundo a qual "a comunidade ideal dos sujeitos moralmente imputáveis [....] entra no tempo histórico e no espaço social, passando pelo medium do Direito, adquirindo uma figura concreta, localizada no espaço e no tempo, enquanto comunidade de direito" (HABERMAS, 2003, p. 140). Habermas (2003, p. 140-141), neste momento, afasta-se do positivismo jurídico, ao reconhecer

\footnotetext{
${ }^{5}$ Cabe destacar que Habermas, diferentemente de Kelsen, não rejeita a possibilidade de uma moral da razão. $\mathrm{Na}$ verdade, a elaboração teórica daquele autor baseia-se no papel complementar que assumem a moral da razão e o Direito positivo. Tanto assim que o item no qual ele aborda o assunto intitula-se "Normas morais e normas jurídicas: sobre a relação de complementaridade entre moral racional e direito positivo" (HABERMAS, 2003, p. 139).
} 
que a aludida intuição não é de todo falsa, "pois uma ordem jurídica só pode ser legítima quando não contrariar princípios morais. Através dos componentes de legitimidade da validade jurídica, o direito adquire uma relação com a moral". No entanto, afasta-se igualmente do jusnaturalismo ao defender que essa relação não deve levar à subordinação do Direito à moral, no sentido de uma hierarquia de normas: "A ideia de que existe uma hierarquia de leis faz parte do mundo pré-moderno do direito. A moral autônoma e o direito positivo, que depende de fundamentação, encontram-se em uma relação de complementaridade recíproca" (HABERMAS, 2003, p. 141).

Habermas (2003, p. 141) segue argumentando que as questões morais e jurídicas referem-se aos mesmos problemas, a saber: "como é possível ordenar legitimamente relações interpessoais e coordenar entre si ações servindo-se de normas justificadas? Como é possível solucionar consensualmente conflitos de ação na base de regras e princípios normativos reconhecidos intersubjetivamente?". Contudo, partem elas de perspectivas distintas. Enquanto a moral representa apenas uma forma de saber cultural, o Direito adquire obrigatoriedade também ao nível institucional. Assim, não é razoável enxergar os direitos fundamentais positivados como simples cópias de normas morais, pois, embora eles possam ter o mesmo conteúdo destas, não possuem os mesmos meios para sua concretização ${ }^{6}$.

Nesse sentido, Habermas procura defender a tese de que a constituição da forma jurídica torna-se necessária a fim de compensar deficits da moral, visto que algumas normas de ação, para alcançar eficácia, carecem não só de juízos corretos e equitativos da moral, mas também, de forma complementar, da obrigatoriedade legitimamente imposta, com o poder de coação próprio do Direito. Mais especificamente, o Direito positivo torna-se necessário para "aliviar" as exigências cognitivas, motivacionais e organizatórias sob as quais se encontra a pessoa que julga e age moralmente (HABERMAS, 2003, p. 148-150).

Em primeiro lugar, Habermas explica que a moral racional configura apenas um procedimento para a avaliação parcial de questões controversas, não possuindo condições de elaborar um catálogo de deveres, nem ao menos uma série de normas hierarquizadas - ela exige somente que os sujeitos formem o seu próprio juízo. O caráter abstrato das normas de uma moral racional - válida universalmente, portanto - levanta problemas de fundamentação e, sobretudo, de aplicação, os quais sobrecarregam a capacidade do indivíduo, fazendo surgir, assim, uma indeterminação cognitiva (HABERMAS, 2003, p. 150-151). Esses problemas, não obstante, são absorvidos pela facticidade da normatização do Direito, uma vez que "O legislador político decide quais normas valem como Direito e os tribunais resolvem, de forma razoável e definitiva para todas as partes, a disputa sobre a aplicação de normas válidas, porém carentes de inter-

${ }^{6}$ Sobre o caráter moral dos direitos humanos, cf. WEYNE (2009). 
pretação" (HABERMAS, 2003, p. 151). Dessa maneira, o sistema jurídico, através da legislação parlamentar e da prática judicial institucionalizada, tira dos destinatários "o peso cognitivo da formação de um juízo moral próprio" (HABERMAS, 2003, p. 151).

Em segundo lugar, Habermas (2003, p. 151) expõe que a moral racional também sobrecarrega o indivíduo com expectativas em relação à sua força de vontade (motivação). Desse modo, o indivíduo "deve conseguir força para agir segundo intuições morais, inclusive contra seus próprios interesses e inclinações, a fim de harmonizar o dever e a obrigação. Enquanto autor [legislador moral], o ator [sujeito] deve concordar consigo mesmo, por ser destinatário de mandamentos" - fica evidente a ideia do princípio kantiano da autonomia da vontade. O indivíduo vê-se, aqui, diante de uma incerteza motivacional sobre o agir orientado por princípios morais conhecidos. Tal incerteza é absorvida pela facticidade da imposição do Direito:

$\mathrm{Na}$ medida em que não está ancorada suficientemente nos motivos e enfoques de seus destinatários, uma moral da razão depende de um Direito que impõe um agir conforme normas, deixando livres os motivos e enfoques. $\mathrm{O}$ Direito coercitivo cobre de tal modo as expectativas normativas com ameaças de sanção, que os destinatários podem limitar-se a considerações orientadas pelas consequências (HABERMAS, 2003, p. 151-152).

Em terceiro lugar, Habermas (2003, p. 152) nota que do caráter universalista da moral racional decorre uma obrigação perante certos deveres positivos, obrigação essa que, nas sociedades complexas, só consegue ser satisfeita a partir de esforços cooperativos ou de realizações organizacionais. Tal autor traz como exemplo o contraste gritante entre o dever inequívoco de impedir que o próximo anônimo morra de fome e o fato de que milhões de habitantes dos países desenvolvidos deixam perecer milhares de pessoas nas regiões pobres dos países de subdesenvolvidos. Segundo ele, problemas como este só podem ser enfrentados em um nível institucional (HABERMAS, 2003, p. 152). Comentando o mesmo assunto, Luiz Moreira (2004, p. 157) esclarece que: "Há um abismo entre a consciência da obrigação moral e os meios para tornar efetivas tais obrigações". Essa exigência organizacional pode ser suprida pelo Direito, porque este é naturalmente reflexivo, possuindo normas secundárias que servem para a produção de normas primárias de orientação da conduta: "Ele [o Direito] pode determinar competências e fundar organizações, em síntese, um sistema de imputabilidade, que se refere não só às pessoas jurídicas naturais, mas também a sujeitos de direitos fictícios, tais como corporações e institutos" (HABERMAS, 2003, p. 153).

Constatando a necessidade do Direito positivo para a superação das dificuldades que sobrecarregam o sujeito que age apenas moralmente, Habermas 
consegue sustentar a tese de que a moral complementa-se pelo Direito e viceversa. Com isso, a moral pode irradiar-se para todos os campos da ação, através de um sistema de direitos, com o qual ela mantém um vínculo interno. Aliás, tal concepção desmistifica, na expressão de Habermas, a representação "platonizante" segundo a qual há uma relação de cópia entre o Direito e a moral, na medida em que esclarece os limites e as potencialidades desses saberes, demonstrando que ambos são autônomos e possuem estruturas e meios distintos para a efetivação das suas determinações.

\section{O Discurso de Justificação do Direito e a Tese da Vinculação Segundo Nino}

Como o próprio Habermas (2003, p. 140-141) insiste em assinalar, "uma ordem jurídica só pode ser legítima quando não contrariar princípios morais. Através dos componentes de legitimidade da validade jurídica, o direito adquire uma relação com a moral". Pois bem, o que se quer agora é justamente demonstrar, com apoio no pensamento de Nino, por que toda e qualquer justificação jurídica depende do recurso à moral.

De acordo com Nino (1990, p. 317), a dependência do discurso jurídico em relação ao discurso moral pode ser provada, e pode sê-lo de uma maneira quase formal. Diante das enormes consequências dessa prova para a sua concepção acerca do Direito, ele a denomina como o teorema fundamental da teoria geral do direito.

Duas explicações prévias são necessárias para a compreensão desse teorema. Em primeiro lugar, entende-se por uma proposição justificatória de uma ação ou decisão "aquela cuja formulação implica certa inconsistência prática com a não realização da ação ou com a adoção da decisão oposta” (NINO, 1990, p. 317). Em segundo lugar, há diversos conceitos de norma jurídica, que podem fazer referência:

por um lado, [1] a uma prática social - ou seja, a uma certa regularidade de ações e atitudes -, [2] a um certo ato linguístico que se executa com a intenção de influir no comportamento dos outros - como quando identificamos as normas jurídicas com prescrições -, [3] a um certo texto - como quando falamos de interpretar uma norma -, e também às proposições que descrevem estes fenômenos ou entidades, ou, por outro lado, [4] a um juízo normativo, ou seja, a uma proposição que qualifica deonticamente uma certa ação (NINO, 1990, p. 317).

Cabe agora averiguar, com Nino, um dos casos mais típicos e claros de raciocínio jurídico justificatório, qual seja, o raciocínio que um juiz utiliza 
para fundamentar uma certa decisão ou uma certa prescrição ${ }^{7}$. Suponha-se, por exemplo, que a justificação imediata de uma ordem de despejo ditada por um juiz seja o juízo a demandada Maria deve ser despejada do imóvel locado. Como o autor explica, tal juízo "constitui uma proposição justificatória no sentido de que seria uma inconsistência prática se o juiz formulasse esse juízo e se negasse a ditar a ordem de despejo de Maria ou se apoiasse a ordem de despejo de Maria na negação desse juízo" (NINO, 1990, p. 317). Diante disso, uma primeira questão que surge é a seguinte: o que pode servir de fundamento desse último juízo que constitui uma proposição justificatória?

Nino (1990, p. 317) responde que o juiz oferecerá como fundamento a conjunção de dois tipos de juízos: "um juízo de fato do tipo Maria não pagou dois meses de aluguel e uma norma jurídica como o proprietário que não recebe dois meses de aluguel tem direito a recuperar o imóvel locado". Segundo Nino, o problema reside em como interpretar este último juízo, que se identifica com uma norma jurídica. Isso porque, dentre os conceitos de norma jurídica vistos anteriormente, os três primeiros conceitos não permitirão, por si só, fundamentar ou derivar a proposição justificatória da ação ou decisão, pois, como explica tal autor:

Pode-se descrever, com verdade, que há uma prática social de despejar quem não paga dois meses de aluguel devolvendo ao proprietário a posse do imóvel locado, ou o ato de alguém de formular uma prescrição dirigida a que se despeje quem não pague dois meses de aluguel, ou a existência de um texto que emprega essas palavras e formular, sem inconsistência prática alguma, o juízo justificatório de que Maria - que não pagou dois meses de aluguel - não deve ser despejada (NINO, 1990, p. 318).

Dessa forma, para que o juízo o proprietário que não recebeu dois meses de aluguel tem direito a recuperar a posse do imóvel locado possa fundamentar a proposição justificatória Maria deve ser despejada, ele só pode ser uma norma jurídica no quarto sentido visto acima, a saber: enquanto um juízo normativo, ou seja, uma proposição que qualifica uma conduta como proibida, como permitida ou como obrigatória (NINO, 1990, p. 318). Nino (1990, p. 318) acrescenta que a norma jurídica enquanto juízo normativo deve-se distinguir de uma prescrição, que "consiste no ato de formular um juízo normativo com a intenção de que essa formulação - em virtude de quem a faz ou das condições em que ela é feita - sirva como razão auxiliar ${ }^{8}$ para o agir de certa pessoa".

\footnotetext{
${ }^{7}$ Optei, nesta parte do texto, por ser fiel ao exemplo de raciocínio jurídico desenvolvido por Nino, a fim de evitar qualquer distanciamento do significado original do seu teorema fundamental da teoria geral do direito, valendo-me inclusive de traduções feitas livremente por mim do artigo desse autor. Cf. NINO (1990, p. 317 et seq.).

8 “[....] uma razão completa está constituída pelo conjunto de um raciocínio prático válido; uma razão operativa consiste na premissa de dever ser que em si mesma poderia constituir uma razão completa para alguma ação; uma razão auxiliar consiste em um juízo fático que indica um meio para satisfazer uma razão operativa" (NINO, 2006, p. 131).
} 
Com essas considerações, já se pode aceitar a tese de que o fundamento de uma proposição justificatória em um típico raciocínio prático jurídico só pode ser uma norma jurídica enquanto um juízo normativo. Para Nino, é razoável, no entanto, perguntar como é possível saber se esse juízo normativo em que o juiz se baseia para fundamentar a sua decisão é, no final das contas, realmente uma norma jurídica.

Para responder essa questão, faz-se necessário revisitar a distinção entre Direito e moral. Nino (1990, 319) - concordando com Kelsen (ver tópico 3) - afirma que o que diferencia Direito e moral não é o conteúdo das suas normas, porque juízos de uma norma jurídica podem ser perfeitamente expressos e interpretados como um juízo moral, "por exemplo, quando [o juízo] é formulado por alguém que ignora o que dispõe a ordem jurídica, ou lhe é indiferente o que ela dispõe, ou sabe que a ordem jurídica nada dispõe a respeito - tem uma lacuna -, ou sabe que dispõe o oposto e sugere modificá-la". Do mesmo modo, Nino (1990, p. 319) sustenta - discordando de Kelsen (ver tópico 3) - que não é tão seguro o critério de acordo com o qual o Direito, ao contrário da moral, determina como devido um ato coativo ou uma sanção, tendo em vista que, além de haver normas jurídicas desprovidas de sanção, existem claros juízos morais que qualificam como permitidos ou devidos atos coativos que têm caráter de penas, como, por exemplo, os assassinos cruéis devem ser submetidos à pena de morte 9 .

Nino esclarece que, se o conteúdo não é um traço distintivo dos juízos normativos jurídicos, então deverá sê-lo a sua origem. Conforme ele, por conseguinte, o que distingue as normas jurídicas das normas morais é o fato de aquelas serem aceitas, no raciocínio prático que justifica uma ação ou uma decisão, por terem sido formuladas por determinada autoridade legislativa ou convencional. Dessa forma,

[....] um juízo do tipo o proprietário que não recebe do seu inquilino dois meses de aluguel tem direito a recuperar o seu imóvel locado só pode ser considerado como uma norma jurídica quando for aceito no raciocínio prático de um juiz, por exemplo, em razão de ter sido previamente aceito um juízo do tipo o legislador L prescreveu que o proprietário que não recebe dois meses de aluguel tem direito a recuperar o seu imóvel (NINO, 1990, p. 319).

Assim, só porque se aceita o segundo juízo é que o primeiro é concebido como uma norma jurídica. Ocorre que um juízo do segundo tipo (prescrição) não possui nenhuma força justificatória, pois é compatível com qualquer

\footnotetext{
9 Não me parece que Nino consegue afastar o argumento de Kelsen a respeito da distinção (formal) entre Direito e moral, haja vista que este autor, antes de analisar a estrutura lógica dos juízos jurídicos e morais, preocupa-se muito mais em demonstrar que o Direito é uma ordem normativa que procura obter uma determinada conduta humana ligando à conduta oposta um ato de coerção socialmente organizado, ao passo que a moral é uma ordem social que não estatui quaisquer sanções desse tipo.
} 
ação ou decisão, independentemente de seu conteúdo. Dessa forma, Nino (1990, p. 320) infere que "é logicamente impossível que alguém aceite o primeiro tipo de juízo pela razão de aceitar o segundo tipo de juízo; se o fizesse, incorreria num óbvio non sequitur", isto é, em um argumento falacioso no qual a conclusão não segue as premissas. Isso significa dizer que um juízo do segundo tipo (prescrição) só pode ser parte da razão pela qual se aceita um juízo do primeiro tipo. A razão operativa ${ }^{10}$ de uma norma jurídica tem de ser fornecida por um terceiro juízo do tipo o legislador $L$ deve ser obedecido ou tem autoridade ou direito para emitir prescrições. Convém, todavia, questionar se esse terceiro juízo, que representa a razão operativa pela qual uma norma jurídica é aceita, é realmente uma norma jurídica.

Como já visto, o que distingue as normas jurídicas das normas morais, para Nino, é a sua origem - ou seja, a razão pela qual elas são aceitas. Conforme tal autor, porém, "essa razão não só deve incluir a descrição daquilo que é prescrito por uma autoridade ou por uma convenção, mas também um juízo normativo que lhes dá autoridade ou legitimidade" (NINO, 1990, p. 320). Logicamente, o processo de justificação de uma norma jurídica não pode seguir ao infinito, de modo que certamente haverá um ponto em que será necessário recorrer a um juízo normativo que não pode ser uma norma jurídica, uma vez que tal juízo não será aceito por ter sido formulado por uma autoridade, mas sim por seus próprios méritos. Como ressalta Nino (1990, p. 320), “um juízo que é aceito não por ter sido formulado por certa autoridade [heteronomia], mas pelos seus próprios méritos, é justamente o que se costuma identificar como um juízo moral - nisto consiste precisamente o traço de autonomia dos juízos morais enfatizado por Kant". O significado da noção de "próprios méritos" dos juízos morais só é explorado por Nino (2007a, p. 110) na sua obra Ética y Derechos Humanos:

O discurso moral está direcionado a obter uma convergência em ações e atitudes, através de uma livre aceitação por parte dos indivíduos, de princípios para guiar suas ações e suas atitudes frente a ações de outros. Este é o traço de autonomia da moral, que foi insuperavelmente assinalado por Kant ao sustentar que o que dá valor moral à ação não é o medo ou a inclinação, mas sim o respeito voluntário à lei, que converte o agente em seu próprio legislador.

Nesse horizonte, o traço distintivo dos juízos morais é que somente eles podem constituir a justificação última (razão final) de uma conduta: "nenhuma razão de outra índole pode prevalecer sobre elas, e elas deslocam qualquer outra razão, quando são aplicáveis. Esta não é uma questão normativa nem motivacional, mas sim lógica [...]” (NINO, 2007a, p. 111).

${ }_{10}$ Como foi visto anteriormente, a razão operativa consiste na premissa de dever ser que em si mesma poderia constituir uma razão completa para alguma ação. 
Diante dessas considerações, conclui-se, com Nino, que as normas jurídicas que estabelecem direitos - como, por exemplo, o proprietário tem direito a recuperar o imóvel locado de quem não pagou dois meses de aluguel - só possuem um caráter justificatório de decisões ou ações quando constituem uma espécie de juízo moral, já que derivam de um juízo moral que legitima certa autoridade e de um juízo de fato que descreve a prescrição dessa autoridade. O citado autor diz mais: "Se concordamos que os direitos que estão estabelecidos por normas morais são direitos morais, daqui se segue que só os direitos morais permitem justificar ações ou decisões" (NINO, 1990, p. 321).

São basicamente esses os argumentos que Nino utiliza para demonstrar o teorema fundamental da teoria geral do direito, segundo o qual o discurso jurídico justificatório é um caso especial do discurso moral, ou seja, depende do discurso moral.

\section{Conclusão}

Embora Habermas aceite a tese da vinculação entre Direito e moral, ele nega que essa relação deva levar à subordinação do Direito à moral no sentido de uma hierarquia de normas, por considerar essa ideia como parte do mundo pré-moderno do Direito. Para ele, Direito e moral são saberes autônomos que se complementam, com estruturas e meios distintos para efetivar as tarefas comuns de ordenar legitimamente as ações interpessoais e de solucionar conflitos de ação na base de regras e princípios intersubjetivamente reconhecidos. Por outro lado, Nino demonstra que a relação de subordinação (dependência) do Direito em face da moral é inevitável quando o tema é a justificação daquele. Ele sustenta que o discurso de justificação do Direito não se pode dar com base em elementos exclusivamente jurídicos, visto que, no processo de justificação de uma ação ou de uma decisão, sempre haverá um momento em que se exigirá uma razão final (moral) que não pode ser, por questões lógicas, uma norma jurídica. Apesar das diferenças de entendimento sobre o tipo de vinculação existente entre Direito e moral, as propostas de Habermas e de Nino aproximam-se quando buscam demonstrar que qualquer ordem jurídica com pretensões de correção e de validade não pode jamais prescindir de certos princípios de moralidade ou de justiça racionalmente justificáveis. É nesse sentido que as contribuições desses autores contemporâneos representam uma superação do tradicional debate entre jusnaturalismo e positivismo jurídico. 


\section{REFERÊNCIAS}

ALEXY, Robert. Conceito e validade do direito. Tradução de Gercélia Batista de Oliveira Mendes. São Paulo: Martins Fontes, 2009.

AQUINO, Tomás de. Suma teológica. Tradução de Aldo Vannuchi et al. São Paulo: Loyola, 2005, v. IV.

ARISTÓTELES. Retórica. Traducción de Alberto Bernabé. Madrid: Alianza Editorial, 1998.

. Ética a Nicômaco. Tradução de Edson Bini. Bauru: EDIPRO, 2002.

BOBBIO, Norberto. Locke e o direito natural. Tradução de Sérgio Bath. Brasília: Universidade de Brasília, 1997.

KANT, Immanuel. Fundamentação da metafísica dos costumes. Tradução de Paulo Quintela. Porto: Porto, 1995.

KELSEN, Hans. Teoria pura do direito. Tradução de João Baptista Machado. 6. ed. São Paulo: Martins Fontes, 2003.

HABERMAS, Jürgen. Direito e democracia: entre facticidade e validade. 2. ed. Tradução de Flávio Beno Siebeneichler. Rio de Janeiro: Tempo Brasileiro, 2003. v. 1.

LOCKE, John. Segundo tratado sobre o governo civil: ensaio sobre a origem, os limites e os fins verdadeiros do governo civil. Tradução de Magda Lopes e Marisa Lobo da Costa. Petrópolis: Vozes, 1994.

MOREIRA, Luiz. Fundamentação do direito em Habermas. 3. ed. Belo Horizonte: Mandamentos, 2004.

NINO, Carlos Santiago. Sobre los derechos morales. Doxa. Cuadernos de filosofía del derecho, Alicante, n. 7, p. 311-325, 1990.

. La validez del derecho. Buenos Aires: Astrea, 2006.

. Ética y derechos humanos: un ensayo de fundamentación. 2. ed. Buenos Aires: Astrea, 2007a. 
. Introducción al análisis del derecho. 2. ed. Buenos Aires: Astrea, 2007b.

OLIVEIRA, Manfredo Araújo de. Ética e sociabilidade. São Paulo: Loyola, 1993.

SCHUMAN, Samuel I. Legal positivism: its scopes and limitations. Detroit: Wayne State University Press, 1963.

WEYNE, Bruno Cunha. A concepção de direitos humanos como direitos morais. Revista direitos fundamentais \& democracia (UniBrasil), Curitiba, v. 6, n. 6, jul./dez. 2009.

\section{LAWAND MORALITYACCORDING TOHABERMASANDNINO}

Abstract: The article aims to present the main theories regarding the relationship between Law and Morality, pointing out the contributions of the contemporary legal philosophy of Jürgen Habermas and Carlos Santiago Nino. In order to accomplish such task, the text is divided into two parts: the first examines the connection and the separation thesis between Law and Morality according to jusnaturalism and legal positivism respectively; the second part analyzes the proposals of Habermas and Nino on the relationship between Law and Morality, and explores how they can overcome the traditional debate.

Keywords: Law and morality. Jürgen Habermas. Carlos Santiago Nino.

Data de recebimento: nov/2010 - Data de aprovação: jan/2011 